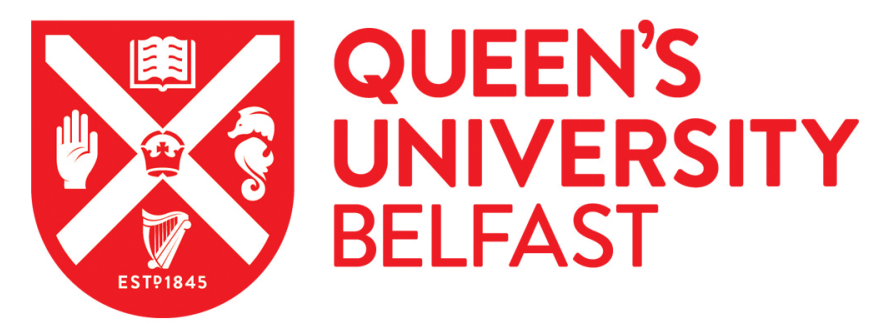

\title{
Wireless Rotating Disk Electrode (wRDE) for assessing Heterogeneous Water Oxidation Catalysts (WOCs)
}

Mills, A., \& O'Rourke, C. (2016). Wireless Rotating Disk Electrode (wRDE) for assessing Heterogeneous Water Oxidation Catalysts (WOCs). Chemical Communications, (49), 7727-7730. https://doi.org/10.1039/c6cc03356c, https://doi.org/DOI: 10.1039/c6cc03356c

Published in:

Chemical Communications

Document Version:

Peer reviewed version

Queen's University Belfast - Research Portal:

Link to publication record in Queen's University Belfast Research Portal

Publisher rights

(C) The Royal Society of Chemistry 2016

\section{General rights}

Copyright for the publications made accessible via the Queen's University Belfast Research Portal is retained by the author(s) and / or other copyright owners and it is a condition of accessing these publications that users recognise and abide by the legal requirements associated with these rights.

Take down policy

The Research Portal is Queen's institutional repository that provides access to Queen's research output. Every effort has been made to ensure that content in the Research Portal does not infringe any person's rights, or applicable UK laws. If you discover content in the Research Portal that you believe breaches copyright or violates any law, please contact openaccess@qub.ac.uk. 


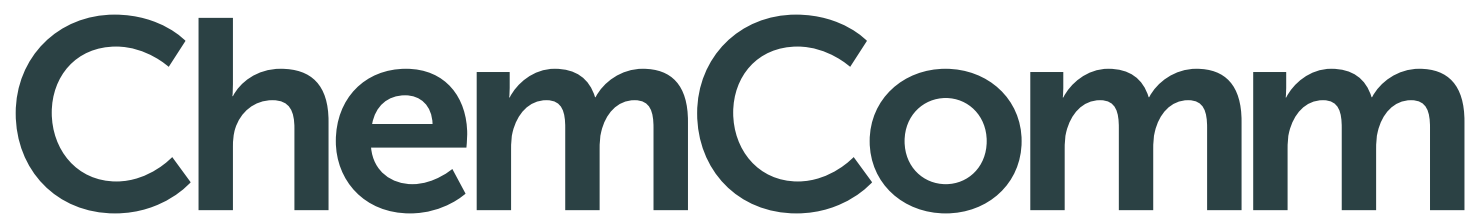

\section{Accepted Manuscript}

This article can be cited before page numbers have been issued, to do this please use: A. Mills and C. O'Rourke, Chem. Commun., 2016, DOI: 10.1039/C6CC03356C.
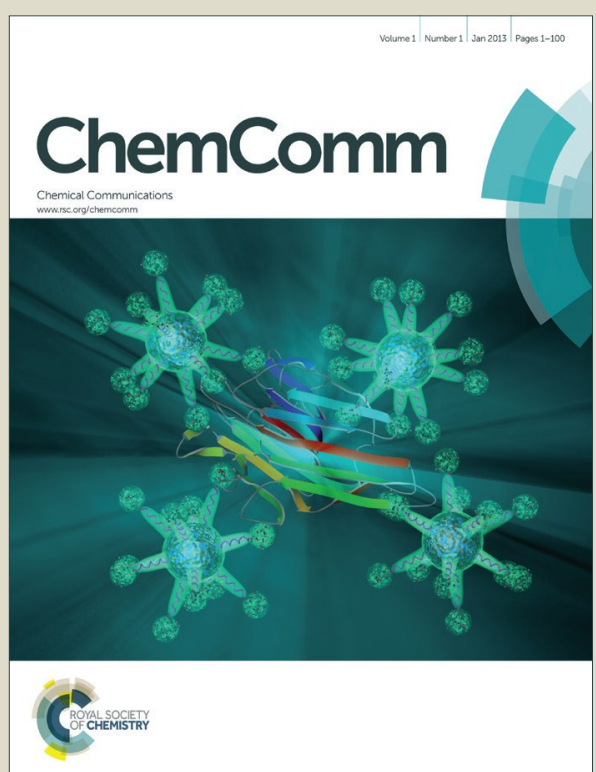

This is an Accepted Manuscript, which has been through the Royal Society of Chemistry peer review process and has been accepted for publication.

Accepted Manuscripts are published online shortly after acceptance, before technical editing, formatting and proof reading. Using this free service, authors can make their results available to the community, in citable form, before we publish the edited article. We will replace this Accepted Manuscript with the edited and formatted Advance Article as soon as it is available.

You can find more information about Accepted Manuscripts in the Information for Authors.

Please note that technical editing may introduce minor changes to the text and/or graphics, which may alter content. The journal's standard Terms \& Conditions and the Ethical guidelines still apply. In no event shall the Royal Society of Chemistry be held responsible for any errors or omissions in this Accepted Manuscript or any consequences arising from the use of any information it contains. 


\section{Journal Name}

\section{Wireless Rotating Disk Electrode (WRDE) for assessing Heterogeneous Water Oxidation Catalysts (WOCs)}

Received 00th January 20xx, Accepted 00th January 20xx

\author{
A. Mills ${ }^{a}$ and C. O'Rourke ${ }^{a}$
}

DOI: $10.1039 / x 0 x \times 00000 x$

www.rsc.org/

A novel method for assessing the activity of a powdered water oxidation catalyst (WOC) is described, utilising an easily-prepared wireless rotating disc electrode of the WOC, thereby allowing its activity to be probed, via the observed kinetics of water oxidation by $\mathrm{Ce}$ (IV) ions, and so provide invaluable electrochemical information.

There is a great deal of interest in the development of efficient, long-lived, low-cost, solar-driven photosystems for the cleavage of water into hydrogen and oxygen ${ }^{1-3}$. One of the great challenges in this work is the identification of a suitable redox catalyst to mediate the oxidation of water, i.e. a water oxidation catalyst, WOC, by the photo-generated oxidant, $O x$, which is usually a valance-band hole in a semiconductor photocatalyst ${ }^{4,5}$. The challenge arises because the oxidation of water is an electrochemically irreversible process, so that most WOCs require a significant overpotential, $\eta$, to drive the reaction at the current densities (ca. $20 \mathrm{~mA} \mathrm{~cm}^{-2}$ ) ${ }^{4}$ that are possible in a very efficient, solar-driven, water-splitting cell ${ }^{4}$. The best WOCs are the oxides of $\mathrm{Ru}$ or $\mathrm{Ir}^{6}$ but, the latter are not abundant $^{4}$ and so there has been a great deal of effort in recent years to identify new, alternative, inexpensive, i.e. Earth-abundant, highly active WOCs ${ }^{3}$.

As part of this effort, many new WOCs are generated in powder form and then screened for activity using a simple redox reaction involving the oxidation of water, i.e. reaction (1).

$$
n O x+2 \mathrm{H}_{2} \mathrm{O} \longrightarrow n \text { Red }+4 \mathrm{H}^{+}+\mathrm{O}_{2} \uparrow
$$

Where $O x$ is the oxidant, Red is the reduced form of $O x$, and $n$ is the number of equivalents necessary to consume 4 electrons from water ${ }^{3,7,8}$; obviously, $O x$ must have an oxidation potential greater than that of water, i.e. $\mathrm{E}(\mathrm{Ox} /$ Red $)>\left\{\mathrm{E}\left(\mathrm{O}_{2} / \mathrm{H}_{2} \mathrm{O}\right)=1.23-0.059 \mathrm{pH}\right\}$. In such screening studies ${ }^{3,8}$, the powdered WOC is commonly dispersed in solution and, upon addition (or photochemical generation) of the oxidising chemical species, $O x$, the rate of

\footnotetext{
School of Chemistry and Chemical Engineering, Queen's University Belfast, Stranmillis Road, Belfast, BT95AG, UK. E-mail: andrew.mills@qub.ac.uk; Fax: +44 (0)289097 6524; Tel: +44 (0)289097 4339

† Electronic supplementary information (ESI) available. See DOI:
}

reaction (1) is measured, usually spectrophotometrically, via its rate of decrease in $[O x]$ with time; this rate is taken as a measure of the activity of the $W_{O C} C^{3,7-9}$. A common chemical oxidant for such work is $\mathrm{Ce}(\mathrm{IV})$, since $\mathrm{E}(\mathrm{Ce}(\mathrm{IV}) / \mathrm{Ce}(\mathrm{III}))=1.44,1.61$ and 1.70 in $1 \mathrm{~N} \mathrm{H}_{2} \mathrm{SO}_{4}$, $\mathrm{HNO}_{3}$ and $\mathrm{HClO}_{4}$ acid, respectively ${ }^{10}$ (see (ESIt: S1)); and, in the absence of a WOC, it is very stable ${ }^{7,8}$. On most conducting electrode materials, the $\mathrm{Ce}(\mathrm{IV}) / \mathrm{Ce}$ (III) redox couple acts a highly reversible (i.e. Nernstian) couple ${ }^{11,12}$, whereas that for water oxidation is highly irreversible ${ }^{6}$.

Reaction (1) is generally used by most to provide only a crude assessment of the activity of the WOC under test, such as initial rate and/or turnover frequency ${ }^{13,14}$. Thus, in order to probe the electrocatalytic properties of a powder-based WOC, a knowledge of which is key if it is to be used in a final, solar-driven, water-splitting device, the powder-based WOC must be fabricated as an anode in what is often a poorly defined, non-trivial and time-consuming process ${ }^{15}$. However, the latter exercise may be unnecessary, since the kinetics of reaction (1) can allow the extraction of useful electrochemical information that relates to the electrocatalytic properties of the powder-based WOC. This option arises because, in most cases, the powder particles of the WOC act simply as microelectrodes that couple, the electrochemical reduction of the oxidant, such as $\mathrm{Ce}(\mathrm{IV})$, with the oxidation of water ${ }^{16}$.

In order to extract out electrochemical information via the kinetics of decay of $O x$, e.g. Ce(IV)) in reaction (1), it is essential that the powder dispersion remains unchanged, i.e. doesn't corrode nor aggregate, during the course of the reaction. The latter condition is often difficult to achieve, especially with low activity WOCs, which exhibit a long reaction time and so provide ample opportunity for extensive aggregation (and often corrosion) to occur. Although the addition of an anti-flocculant can help reduce this effect, such additives will necessarily affect the intrinsic electrochemical characteristics of the WOC under test that are being probed ${ }^{17}$.

Herein we describe a simple, quick method for fabricating a wireless, i.e. no external electrical contact, rotating disc electrode, $W R D E$, of a powdered $W O C$, here, primarily, $\mathrm{RuO}_{2}$ (Adams), which allows the electrochemical characteristics of the WOC to be readily probed, via the measured kinetics of decay of $\mathrm{Ce}$ (IV) in reaction (1). 
In this work, the powdered WOC under test was the blackcoloured powder, $\mathrm{RuO}_{2}$ (Adams), the preparation of which has been described elsewhere ${ }^{18}$. A schematic illustration of the general method of preparation of the WRDE of this WOC is illustrated in figure 1 and full details, and photographs of the final product, are given in (ESIt: S2).

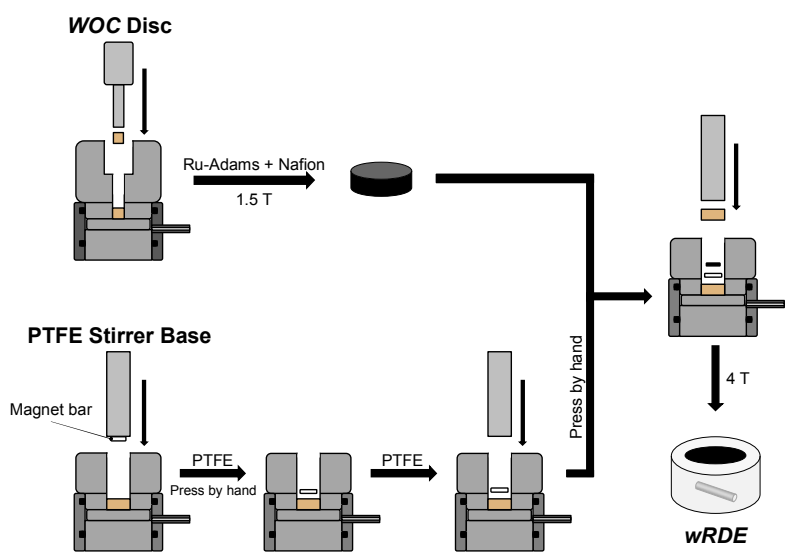

Figure 1 Schematic illustration of the preparation of a $\mathrm{RuO}_{2}$ (Adams) WRDE.

The electrochemical properties of the $\mathrm{RuO}_{2}$ (Adams) $W R D E$ were probed by placing it in a spectrophotometer cuvette containing 1.5 $\mathrm{ml} 0.5 \mathrm{M} \mathrm{H}_{2} \mathrm{SO}_{4}$ solution, thermostatted at $30^{\circ} \mathrm{C}$, and spinning it continuously at $1000 \mathrm{rpm}$ using a magnetic stirrer. The water oxidation reaction (1) was initiated by injecting, into the solution in the cuvette, $54 \mu \mathrm{L}$ of a $0.1 \mathrm{M} \mathrm{Ce}$ (IV) sulfate in $0.1 \mathrm{~N} \mathrm{H}_{2} \mathrm{SO}_{4}$ (Aldrich Chemicals). The subsequent change in the absorbance, at $430 \mathrm{~nm}$, of the reaction solution was measured as a function of time, using a Cary 60 spectrophotometer. A typical set of absorption spectral changes, derived from such a typical kinetic run, are illustrated in figure 2. The insert diagram shows the measured decays in absorbance, due to Ce(IV) for two serial injections of Ce(IV). The two decays are identical and near perfect $1^{\text {st }}$ order with respect to $\mathrm{Ce}(\mathrm{IV})$ concentration, $[\mathrm{Ce}(\mathrm{IV})]_{\mathrm{t}}$, yielding a value for the first order rate constant, $k_{1}=0.0149 \mathrm{~min}^{-1}$, over 3 half-lives, and correlation coefficient $>0.9999$. Previous work carried out using this $W O C$ has established the generation of stoichiometric amounts of $\mathrm{O}_{2}$ via reaction (1) under the same conditions ${ }^{16}$. In this system a value of the molar Ce:Ru ratio, $\theta$, for just one injection of $\mathrm{Ce}(\mathrm{IV}) 9.6 \times 10^{-5}$ can be calculated ${ }^{19}$ which suggests that it is operating under catalytic conditions. Details of this calculation can be found in (ESIt: S3).

From the identical natures of the two decay profiles illustrated in figure 2 it is clear that the rate of reaction (1) is independent of the concentration of $\mathrm{Ce}(\mathrm{III})$, i.e. $[\mathrm{Ce}(\mathrm{III})]_{\mathrm{t}}$, generated during the course of reaction, at reaction time $t$. This suggests that the rate is independent of the redox potential of the $\mathrm{Ce}(\mathrm{IV}) / \mathrm{Ce}$ (III) couple in solution, which, according to the Nernst equation, would change, as the $[\mathrm{Ce}(\mathrm{IV})]_{\mathrm{t}}:[\mathrm{Ce}(\mathrm{III})]_{\mathrm{t}}$ ratio changes, during the course of reaction (1).

Many researchers working on WOCs favour using cerium ammonium nitrate (CAN) as the oxidant and $1 \mathrm{M} \mathrm{HNO}_{3}$ as the acid. Thus, (i) to show that such a medium is appropriate for work with a $W R D E$, (ii) provide further support for the electrochemical model presented here and (iii) to emphasise further the catalytic nature of the $\mathrm{RuO}_{2}$ (Adams), the $\mathrm{CAN} / 1 \mathrm{M} \mathrm{HNO}$ system was used to test the $\mathrm{RuO}_{2}$ (Adams) WRDE. The results from this work revealed the same 1st order kinetics of Ce(IV) decay, using either $3.6 \times 10^{-3}$ or $0.1 \mathrm{M}$ CAN, in $1 \mathrm{M} \mathrm{HNO}_{3}$, as illustrated by the decay profiles and photographs in (ESIt: S4).

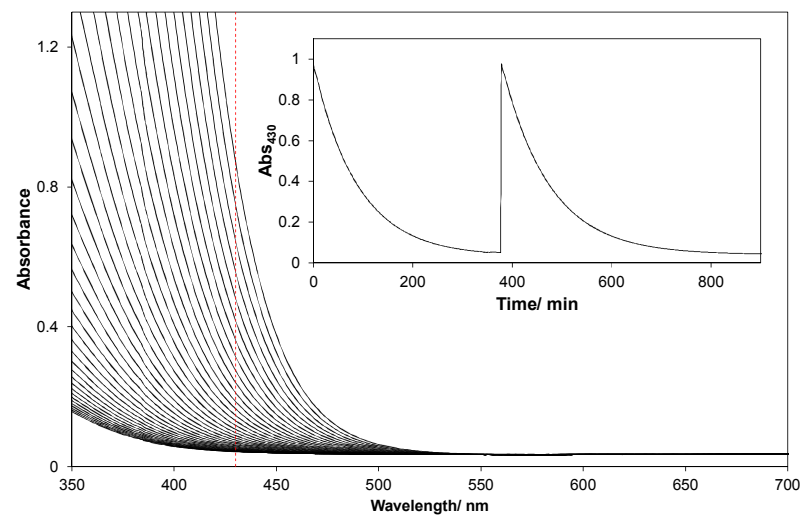

Figure 2 Change in the UV/Vis spectra upon the $1^{\text {st }}$ injection of $54 \mu \mathrm{L}$ of $0.1 \mathrm{M} \mathrm{Ce}\left(\mathrm{SO}_{4}\right)_{2}$ into $1.5 \mathrm{~mL}$ of $0.5 \mathrm{M} \mathrm{H}_{2} \mathrm{SO}_{4}$. The red broken line indicates the wavelength at which the reduction of $\mathrm{Ce}(\mathrm{IV})$ is monitored, i.e. $430 \mathrm{~nm}$. The inset shows a plot of the decay of $\mathrm{Ce}(\mathrm{IV})$ over 2 serial injections. In all cases the $W R D E$ rotation speed $=1000 \mathrm{rpm}$ and reaction temperature $=30^{\circ} \mathrm{C}$.

At a conventional, i.e. wired, $R D E$, when the rate of reduction of a oxidising species, such as $\mathrm{Ce}(\mathrm{IV})$, is independent of applied potential, the reaction is diffusion-controlled and the measure current obeys the Levich equation ${ }^{11,12}$ :

$$
i_{d}=0.62 \cdot n \cdot F \cdot A \cdot D^{2 / 3} \omega^{1 / 2} v^{-1 / 6}[\mathrm{Ox}]
$$

where, $i_{d}=$ diffusion limited current (A), $n=$ number of electrons transferred during the reduction reaction, $\mathbf{F}=$ Faraday's constant $(\mathrm{C} / \mathrm{mol}), A=$ electrode area $\left(\mathrm{cm}^{2}\right), \mathrm{D}=$ diffusion coefficient for $O x$ $\left(\mathrm{cm}^{2} / \mathrm{s}\right), \omega=$ rotation speed angular rate of rotation of the electrode $(\mathrm{rads} / \mathrm{s}), \mathrm{v}=$ kinematic viscosity $\left(\mathrm{cm}^{2} / \mathrm{s}\right)$ and $[\mathrm{Ox}]=$ concentration of oxidant $\left(\mathrm{mol} / \mathrm{cm}^{3}\right)$. The observation of excellent $1^{\text {st }}$ order kinetics for the $\mathrm{Ce}$ (IV) reduction on the $\mathrm{RuO}_{2}$ (Adams) WRDE, see figure 2, suggests that in this system the rate of reaction (1), with $O x=$ $\mathrm{Ce}(\mathrm{IV})$, is diffusion-controlled and, as such, should obey the following modified version of the Levich equation:

$$
\text { rate }(\mathrm{M} / \mathrm{s})=k_{d}[\mathrm{Ce}(\mathrm{IV})]_{\mathrm{t}}=0.62 \cdot A \cdot \mathrm{D}^{2 / 3} \omega^{1 / 2} \mathrm{v}^{-1 / 6}[\mathrm{Ce}(\mathrm{IV})]_{\mathrm{t}} / V
$$

where $k_{d}$ is the measured value for the first order rate constant under these conditions, $V$ is the reaction solution volume $\left(\mathrm{cm}^{3}\right)$. Given $A=0.196 \mathrm{~cm}^{2}, V=1.554 \mathrm{~cm}^{3}, v=0.01 \mathrm{~cm}^{2} / \mathrm{s}$, it follows that eqn(3) predicts the following relationship between $k_{d}$ (i.e. the measured value of $k_{1}$ at $30^{\circ} \mathrm{C}$ ) and the rotation speed of the $W R D E$, $\omega:$

$$
k_{d}=0.168 \cdot \mathrm{D}^{2 / 3} \omega^{1 / 2}
$$

In order to test this predicted relationship, the same conditions as used to generate the data in figure 2 were employed, but with the rotation speed of the $W R D E$ varied systematically $(100-1300 \mathrm{rpm})$ in a series otherwise identical kinetic runs involving reaction (1), with $O x=\mathrm{Ce}(\mathrm{IV})$. In all cases the kinetics of $\mathrm{Ce}(\mathrm{IV})$ decay were monitored 
spectrophometrically and yielded excellent $1^{\text {st }}$ order plots of the decay data over 3 half-lives $\left(r^{2}>0.9999\right)$.

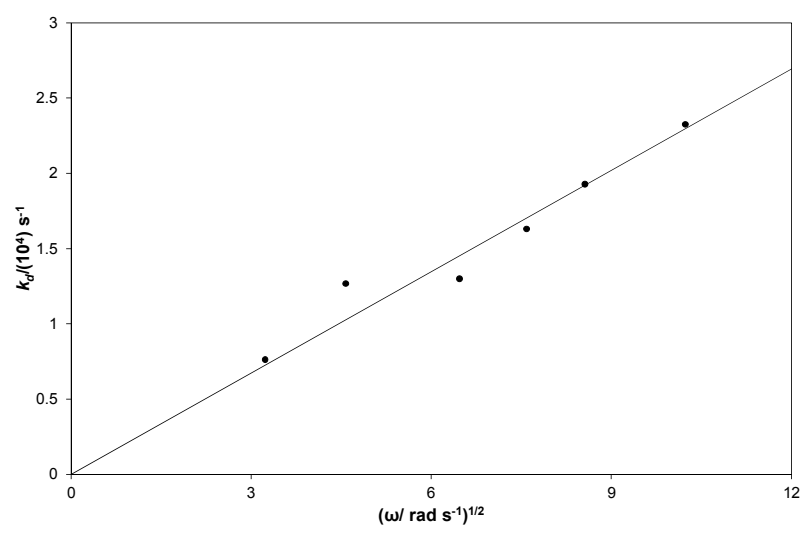

Figure 3 Plot of the 1 st order rate, $k_{d}$, of reduction of $\mathrm{Ce}$ (IV) using the WRDE as a function of the square root of the rotation speed. Reaction conditions: otherwise as in figure 1.

A plot of the $k_{d}$ values derived from this work versus $\omega^{1 / 2}$ is illustrated above in figure 3 and yields a gradient $=2.25 \times 10^{-5}$, from which a value for the diffusion coefficient, $D$, of $1.55 \times 10^{-6} \mathrm{~cm}^{2} / \mathrm{s}$ was calculated using eqn (4). The latter appears low when compared to reported ${ }^{11,12}$ values for $D$ for Ce(IV) on Pt electrodes (3.4-5) $\times 10^{-6}$ $\mathrm{cm}^{2} / \mathrm{s}$, although this may be because the actual value for $A$ was lower than the geometric value used in the calculations. The latter situation would occur if a significant part of the WOC in the WRDE was not electro active, which would happen if, as well as naked $\mathrm{RuO}_{2}$ (Adams) particles, the surface comprised regions of pure Nafion, or Nafion-covered $\mathrm{RuO}_{2}$, particles. Initial optical and electron micrographs of the $\mathrm{RuO}_{2}$ (Adams) WRDE provide some evidence for this.

Unfortunately, although the $\mathrm{RuO}_{2}$ (Adams) $w R D E$ appears to obey the Levich equation, this doesn't actually probe the electrocatalytic activity of the $\mathrm{RuO}_{2}$ (Adams) as such, since the kinetics are diffusion-controlled. Instead, experimental conditions need to be used under which the kinetics is no longer purely diffusion controlled. In this work, this was simply achieved by running the same experiment as above, but at a much lower temperature, since the activation-controlled oxidation of water is much more temperature sensitive $\left(E_{a}=38-55 \mathrm{~kJ} / \mathrm{mol}\right)^{6}$ than the diffusion-controlled reduction of $\mathrm{Ce}(\mathrm{IV})\left(\mathrm{E}_{\mathrm{a}}=\mathrm{ca} .15 \mathrm{~kJ} / \mathrm{mol}\right)^{20}$, so that lower temperatures will favour activation-, rather than diffusion-, -controlled kinetics for reaction (1) using the $\mathrm{RuO}_{2}$ (Adams) wRDE.

Thus, the absorbance decay plots illustrated in figure 4, were generated for three serial injections of $\mathrm{Ce}(\mathrm{IV})$, using the same reaction conditions as used in figure 1 , but with a reaction temperature of $5^{\circ} \mathrm{C}$, rather than $30^{\circ} \mathrm{C}$. The results show that, unlike those recorded at $30^{\circ} \mathrm{C}$, at $5^{\circ} \mathrm{C}$ the kinetics of reaction (1) are dependent upon the amount of $\mathrm{Ce}(\mathrm{III})$ generated, i.e. the reaction slows down as the redox potential, due to the $\mathrm{Ce}(\mathrm{IV}) / \mathrm{Ce}$ (III) couple, decreases with increasing reaction time, $t$.

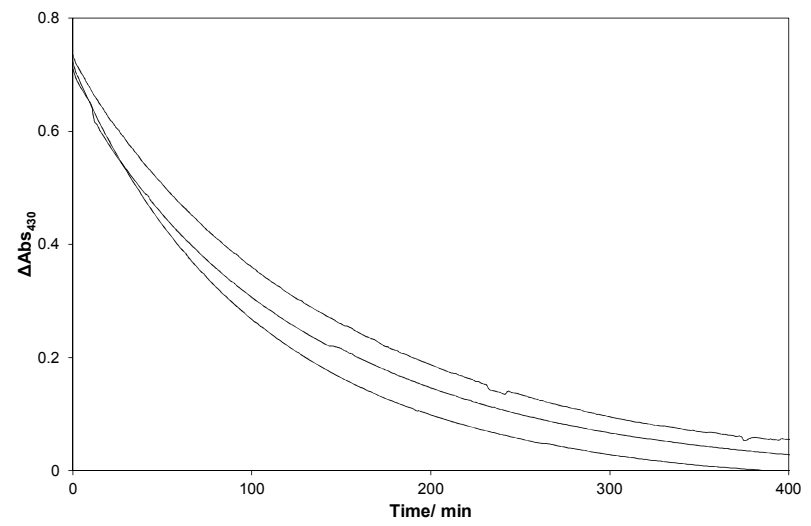

Figure $4 \Delta \mathrm{Abs}_{430}$ vs time upon 3 serial injections of $54 \mu \mathrm{L}$ of $0.1 \mathrm{M} \mathrm{Ce}\left(\mathrm{SO}_{4}\right)_{2}$ into $1.5 \mathrm{~mL}$ of $0.5 \mathrm{M} \mathrm{H}_{2} \mathrm{SO}_{4}$ at $5^{\circ} \mathrm{C}$. Rotation speed $=1000 \mathrm{rpm}$.

As commented earlier, in redox catalysis it is recognised ${ }^{21}$ that the role of the catalyst is often simply that of a conductor of electrons from one redox couple - in this case $O x /$ Red in reaction (1) - to another, i.e. $\mathrm{O}_{2} / \mathrm{H}_{2} \mathrm{O}$ in reaction (1). It follows that at any time during a $\mathrm{Ce}(\mathrm{IV})$ decay, such as illustrated in figure 4 , each dispersed $\mathrm{RuO}_{2}$ (Adams) WOC particle is poised at a mixed potential, $E_{\text {mix }, t}$, so as to allow a 'mixed' current, $i_{\text {mix }, t}$, to flow through it, with a numerical value that is the same for both the anodic and cathodic electrochemical processes that are occurring concomitantly at separate sites on the redox catalyst. The Nernstian nature of the $\mathrm{Ce}(\mathrm{IV}) / \mathrm{Ce}(\mathrm{III})$ electrochemical process allows the value of $E_{m i x, t}$ at any time $t$ during a decay, such as illustrated in figure 4 , to be calculated ${ }^{16}$ via:

$$
E_{m i x, t}=E_{C e}^{\prime}+(\mathbf{R} T / \mathbf{F}) \ln \left\{\left[-k_{d}[\mathrm{Ce}(\mathrm{IV})]_{\mathrm{t}}-r(t)\right] /\left[r(t)-k_{d}[\mathrm{Ce}(\mathrm{III})]_{\mathrm{t}}\right]\right\}
$$

where, $E_{C e}^{\prime}=1.44 \mathrm{~V}$ vs NHE in $0.5 \mathrm{M} \mathrm{H}_{2} \mathrm{SO}_{4}, k_{d}=$ the diffusioncontrolled rate constant $\left(\mathrm{s}^{-1}\right)$ and $r(t)=$ the rate of $\mathrm{Ce}(\mathrm{IV})$ reduction at time $t\left(=d[\mathrm{Ce}(\mathrm{IV})]_{\mathrm{t}} / d \mathrm{t}\right.$ ). Since, on any $\mathrm{RuO}_{2}$ (Adams) particle, the electrochemical reduction of $\mathrm{Ce}(\mathrm{IV})$ is coupled to the oxidation of water, it follows that the latter, irreversible process, can be related to the rate of $\mathrm{Ce}(\mathrm{IV})$ reduction by the following expression:

$$
r(t)=r_{w} \cdot \exp \left\{2.303\left(E_{m i x, t}-E_{w}^{\prime}\right) / b\right\}
$$

where, $r_{w}=$ a constant that is related directly to the exchange current density for water oxidation, $E^{\prime}{ }_{w}=$ the formal redox potential of the $\mathrm{O}_{2} / \mathrm{H}_{2} \mathrm{O}$ couple (here, taken as: $1.23 \mathrm{~V}$ vs NHE) and $b=$ Tafel slope. It follows from eqn (6) that a plot of $E_{\text {mix, }}$ vs $\log \{r(t)\}$ should yield a straight line with a gradient, $b$. At any reaction time $t$, for any of the decay curves illustrated in figure 4 , it is possible to calculate appropriate values for: $r(t),[\mathrm{Ce}(\mathrm{IV})]_{\mathrm{t}},[\mathrm{Ce}(\mathrm{III})]_{\mathrm{t}}$ and so a value for $E_{\text {mix,t }}$, using eqn (5). The results of this type of analysis of all the decay data illustrated in figure 4 are illustrated in figure 5 and reveal an approximate Tafel slope of $54 \pm 2 \mathrm{mV} /$ decade and an extrapolated value for $r(t)=1.04 \times 10^{-8} \mathrm{M} / \mathrm{min}$ at $E_{\text {mix }, t}=1.23 \mathrm{~V}$.

For $\mathrm{RuO}_{2}$, the reported Tafel slope for oxygen evolution varies between 40 and $120 \mathrm{mV}$, depending how it is prepared ${ }^{6}$. A value of $65 \mathrm{mV} /$ decade at $25^{\circ} \mathrm{C}$ in $0.5 \mathrm{M} \mathrm{H}_{2} \mathrm{SO}_{4}$ has been reported previously for $\mathrm{RuO}_{2}$ films grown on Ru metal ${ }^{22}$. A value of $60 \mathrm{mV} /$ decade at $25^{\circ} \mathrm{C}$ ( $\equiv 56 \mathrm{mV} /$ decade at $5^{\circ} \mathrm{C}$ ) may be derived from theory if the 
deprotonation of the reaction site $\mathrm{S}-\mathrm{OH}$ is the rate determining step, as proposed by Krasil'shchikov ${ }^{6,23}$, i.e.:

$$
\mathrm{S}-\mathrm{OH} \longrightarrow \mathrm{S}^{-}+\mathrm{H}^{+}
$$

From the data in figure 5, given that at $E_{m i x, t}=1.23 \mathrm{~V}, \equiv E_{w}^{\prime}$, the value of $r(t), \equiv r_{w}$ in eqn $(6),=1.04 \times 10^{-8} \mathrm{M} / \mathrm{min}$, which in turn is $\equiv$ $1.32 \mu \mathrm{A} / \mathrm{cm}^{2}$, given $A=0.196 \mathrm{~cm}^{2}$ and $V=1.554 \mathrm{~cm}^{3}$. It follows that, in order to oxidise water to $\mathrm{O}_{2}$ on the WRDE Ru(Adams) electrode at a current density $=20 \mathrm{~mA} / \mathrm{cm}^{2}$, an overpotential, $\equiv$ $\left(E_{\text {mix,t }}-E_{w}^{\prime}\right)$ in eqn(6), of $226 \mathrm{mV}$ will be required. This value is in reasonable agreement with the work ${ }^{22}$ referred to earlier on $\mathrm{RuO}_{2}$ films grown on Ru metal, for which a value of $\eta=270 \mathrm{mV}$ can be calculated.

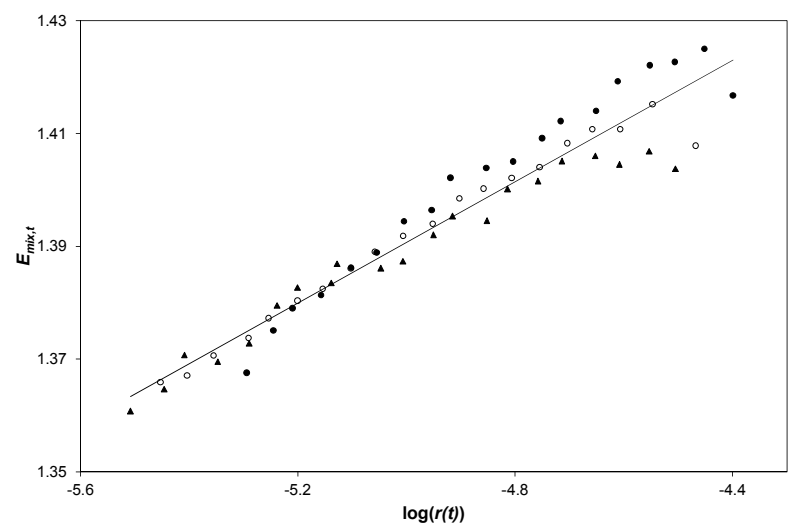

Figure 5 Tafel plot of the data in figure 5 giving a slope of $54 \mathrm{mV}$ per decade and a $k_{d}$ value of $0.015 \mathrm{~min}^{-1}$. The units of $r(t)$ here are $\mathrm{M} / \mathrm{min}$.

Table 1 List of Tafel slopes, $b$, the rate at a potential of $1.23 \mathrm{~V}, r_{w}$, and the calculated overpotential, $\eta$ (at a current density of $20 \mathrm{~mA} / \mathrm{cm}^{2}$ ), derived from the data in (ESIt: S5, figure S5).

\begin{tabular}{cccc}
\hline Catalyst & $\boldsymbol{b} / \mathbf{m V}$ per decade & $\eta / \mathbf{m V}$ & $\boldsymbol{r}_{w} /\left(\mathbf{1 0}^{9}\right) \mathbf{M ~ m i n}^{-1}$ \\
\hline $\mathrm{RuO}_{2}$ (Adams) & 54 & 226 & 10.4 \\
$\mathrm{IrO}_{2}$ & 58 & 280 & 2.34 \\
$\mathrm{PtO}_{2} \ddagger$ & 125 & 478 & 23.7 \\
\hline
\end{tabular}

₹ Run in $1 \mathrm{~N} \mathrm{HNO}_{3}$ at $30^{\circ} \mathrm{C}$, all other wRDE's were run in $1.5 \mathrm{~mL}$ of $1 \mathrm{~N} \mathrm{H}_{2} \mathrm{SO}_{4}$ at $5^{\circ} \mathrm{C}$.

Other WRDE's were prepared using commercial forms of IrO $2.2 \mathrm{H}_{2} \mathrm{O}$ (Alfa Aesar) and $\mathrm{PtO}_{2}$ (Sigma Aldrich) and tested using the $\mathrm{Ce}(\mathrm{IV})$ decay system yielding Tafel plots that are illustrated in (ESI+: S5), from which the values of $b$ and $\eta$ listed in Table 1 were derived. The difference in the $\eta$ value for $\mathrm{IrO}_{2}$, to that of $\mathrm{RuO}_{2}$ (Adams), (54 $\mathrm{mV})$ is consistent with that $(60 \mathrm{mV})$ reported by others recently for sputtered films of the same oxides ${ }^{24} . \mathrm{PtO}_{2}$ has been reported previously as a $W O C$ for reaction (1) in $1 \mathrm{~N} \mathrm{H}_{2} \mathrm{SO}_{4}$, albeit of low activity $^{25}$, where $O x=\mathrm{Ce}(\mathrm{IV})$, and so was studied here, as a $W R D E$, although under more oxidising conditions (i.e. in $1 \mathrm{M} \mathrm{HNO}_{3}$, vide supra) for which $\mathrm{E}_{\mathrm{Ce}}^{\prime}$ is $1.61 \mathrm{~V}^{10}$, in order to generate a more easily measured decay. The values of $b$ and $\eta$ derived from this work for $\mathrm{PtO}_{2}$, see Table 1, are in reasonable agreement with those reported by others for the same material and acid (i.e. $b=109 \mathrm{mV} /$ decade; $\eta$ $=500 \mathrm{mV})^{6}$.

\section{Conclusions}

In summary, the construction of a wireless rotating disc electrode, $w R D E$, of a water oxidation catalyst, in this case $\mathrm{RuO}_{2}$ (Adams), is reported. This method allows powdered materials, which might be able to act as WOCs, to be assessed for catalytic activity using a suitable reversible redox couple, such as $\mathrm{Ce}(\mathrm{IV}) / \mathrm{Ce}(\mathrm{III})$.

\section{Acknowledgements}

We thank DEL and the US/Ireland R\&D Partnership programme (USI 049) for funding this work.

\section{Notes and references}

1 N. S. Lewis and D. G. Nocera, Proc. Natl. Acad. Sci. USA, 2006, 103, 15729-15735.

2 H-J. Lewerenz, L. Peter, Photoelectrochemical Water Splitting: Materials, Processes and Architectures, RSC Publishing, Cambridge, 2013.

3 J. R. Galán-Mascarós, ChemElectroChem, 2015, 2, 37-50.

4 M. G. Walter, E. L. Warren, J. R. McKone, S. W. Boettcher, Q. Mi, E. A. Santori and N. S. Lewis, Chem. Rev., 2010, 110, 6446-6473.

5 Y. W. Chen, J. D. Prange, S. Dühnen, Y. Park, M. Gunji, C. E. D. Chidsey and P. C. McIntyre, Nat. Mater., 2011, 10, 539-544.

6 S. Trasatti and G. Lodi, Electrodes of Conductive Metallic Oxides, Part B, S. Trasatti (ed.), Elsevier, Amsterdam, 1981, ch. 10.

7 A. R. Parent, R. H. Crabtree and G. W. Brudvig, Chem. Soc. Rev., 2013, 42, 2247-2252.

8 A. Mills, Chem. Soc. Rev., 1989, 18, 285-316.

9 B. Limburg, E. Bouwman and S. Bonnet, Coord. Chem. Rev., 2012, 256, 1451-1467.

10 Ionic Equilibria in Analytical Chemistry, J-L. Burgot, Springer, New York, 2012, p. 395.

11 T. H. Randle and A. T. Kuhn, J. Chem. Soc. Faraday Trans. 1, $1983,79,1741-1756$.

12 R. Greef and H. Aulich, Electroanal. Chem. Interfac. Chem., 1968, 18, 295-307.

13 F. Jiao and H. Frei, Energy Environ. Sci., 2010, 3, 1018-1027.

14 M. M. Najafpour, T. Ehrenberg, M. Wiechen and P. Kurz, Angew. Chemie, 2010, 49, 2233-2237.

15 J-I Jung, H. Y. Jeong, J-S Lee, M. G. Kim, J. Cho, Angew. Chem. Int. Ed., 2014, 53, 4582-4586.

16 A. Mills and H. Davies, Electrochim. Acta, 1992, 37, 12171225.

17 A. Mills and G. Meadows, J. Chem. Soc., Faraday Trans., 1993, 89, 3849-3850.

18 A. Mills, D. Hazafy, S. Elouali and C. O'Rourke, J. Materials Chem. A, 2016, 4, 2863-2872.

19 R.L. Doyle, I.J. Goodwin, M.P. Brandon and M.E.G. Lyons, Phys. Chem. Chem. Phys., 2013, 15, 13737-13783.

20 F. Wilkinson, Chemical Kinetics and Reaction Mechanisms, Van Nostrand Reinhold, London, 1981, p. 140.

21 M. Spiro, Chem. Soc. Rev., 1986, 15, 141-165.

22 J. Horkans and M. W. Shafer, J. Electrochem. Soc., 1977, 124, 1202-1207.

23 A.I. Krasil'shchikov, Zh. Fiz. Chim., 1963, 37, 273-275.

24 C.C.L. McCory, S. Jung, I.M. Ferrer, S. M. Chatman, J. C. Peters and T.F. Jaramillo, J. Am. Chem. Soc.,, 2015, 137, 4347-4357.

25 J. Kiwi and M. Gratzel, Angew. Chem. Int. Engl. 1978, 17, 860-861. 